\title{
Evaluation of Growth Performance, IL-6 and Serum Biochemical Parameters of Rats Fed on Diets Containing Thyme and Ginger Powder
}

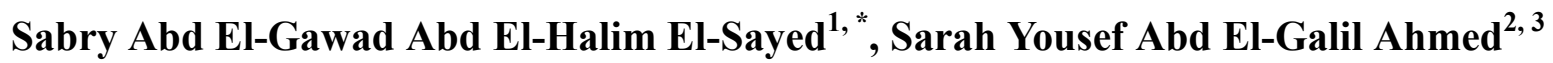 \\ ${ }^{1}$ Department of Nutrition and Clinical Nutrition, Faculty of Veterinary Medicine, Zagazig University, Zagazig, Egypt \\ ${ }^{2}$ Microbiology Department, Faculty of Veterinary Medicine, Zagazig University, Zagazig, Egypt \\ ${ }^{3}$ Department of Clinical Laboratory Sciences, College of Applied Medical Science, University of Hail, Hail, Saudi Arabia
}

Email address:

drsabry80@gmail.com (S. A. El-Gawad A. El-Halim El-Sayed), sarahyousef_xp@yahoo.com (S. Y. A. El-Galil Ahmed)

${ }^{*}$ Corresponding author

\section{To cite this article:}

Sabry Abd El-Gawad Abd El-Halim El-Sayed, Sarah Yousef Abd El-Galil Ahmed. Evaluation of Growth Performance, IL-6 and Serum Biochemical Parameters of Rats Fed on Diets Containing Thyme and Ginger Powder. Animal and Veterinary Sciences.

Vol. 4, No. 5, 2016, pp. 78-85. doi: 10.11648/j.avs.20160405.12

Received: September 26, 2016; Accepted: October 7, 2016; Published: October 31, 2016

\begin{abstract}
Antibiotics have been extensively used as feed additives and growth performance in animal feed industry. The use of antibiotics is hazardous due to multiple resistances of pathogens. Thyme and ginger are medicinal herbs which have antiinflammatory, antimicrobial, and antioxidant properties and used as feed additives in animal industry. Thus, the present study carried out to estimate the effect of thyme and ginger on some biochemical and immunological parameters in addition to their effect on the growth performance. Fifteen male rats were divided into three groups, first one was fed on basal diet (the control), second group was fed on basal diet contained thyme (5\%) and the third was fed on basal diet contained ginger $(5 \%)$. The experiment lasts for 4 weeks and then serum sample was collected. Our results revealed the presence of significantly increase in body weight; body gain and feed efficiency values in treated groups in comparison with the control group. Total globulins and alkaline phosphatase (ALP) were significantly increased for ginger and thyme groups in comparing with control group meanwhile total proteins and albumin recorded non-significant change, GOT increased in ginger group but not in thyme one. Thyme and ginger decreased triglyceride (TG), total cholesterol (TC) and low density lipoproteins (LDL) even though high density lipoproteins (HDL) showed no significant change in either group. Thyme decreased serum urea and Creatinine meanwhile ginger increased serum Creatinine with no significant change of urea. On the other hand Thyme significantly decreases production of serum Interleukin 6 (IL-6) in mice while ginger increased its level in serum. The present study concluded that either thyme or ginger have positive effect on some biochemical and immunological parameters in addition to their effect on growth performance however they have negative effect on others, as this is the first recorded increase of ALP with the two herbs so the using of the herbs must under restriction.
\end{abstract}

Keywords: Thyme Powder, Ginger Powder, Growth Performance, Biochemical Parameter, Interleukin 6, Rats

\section{Introduction}

Herbs are natural alternatives to antibiotic growth promoters (AGPs) in animal nutrition due to their antimicrobial properties. Many herbs and their bio-active constituents possess a broad antimicrobial activity, and appetite and digestion stimulating effects [1]. Herbal plants have stimulatory effects on pancreatic secretions such as digestive enzymes which help to digest and absorb more amino acids from the digestive tract [2]. Herbal growth promoter (essential oil) had significant improvement of body weight, weight gain, and feed conversion in Japanese quail [3]. Thyme (Thymus vulgaris L.) is one of the popular medicinal plant mostly grown in Mediterranean region and is one of the herbal plants that have received attention as it has antioxidant and anti-bacterial [4, 5, 6], free radical scavenging properties [7], antifungal [8], antirheumatic, 
carminative $[9,10]$, antiparastic, analgesic, hypotensive agent [11], anti-inflammatory [12], immunomodulating effect [13]. Thyme can be used traditionally for several medicinal purposes: respiratory disease, antimicrobial and antinociceptive [14]. Supplementation with thyme oil improved the growth performance and antioxidant enzyme activities in rainbow trout (Oncorhynchusmykiss) juveniles [15]. Thyme contains volatile oil (consisting of 55\% phenols) thymol and carvacral [16], thymine [10], numerous types of flavonoids and vitamin E [17, 18]. Carvacrol possesses antimicrobial, antifungal, and antioxidant activities as well as antimutagenic and anticarcinogenic effects [19, 20, 21]. Physiological and biochemical effect of the thyme was studied by many researchers, they show that thyme cause hypoglycemia and increase in appetite, also significant decrease in plasma HDL, total lipids total, cholesterol and triglycerides levels [22]. Moreover, Feeding thyme resulted in a marked increase in HDL- cholesterol concentration [23]. Dietary thyme oil increases plasma level of triglycerides, LDL-cholesterol and HDL-cholesterol in broilers [24]. Administration of ginger and garlic to broiler chickens increased their performance and boosted their immunity [25]. Ginger contains several compounds including gingerdiol, gingerol, gingerdione and shogaols [26]. These compounds have been blocking the production of interleukins, and inflammatory markers [27, 28] and have antimicrobial, antioxidative and pharmacological effects [29]. Also, gingerol is the major ingredient representing a variety of bioactivities including antitumor promotional and antiproliferative [30]. IL-6 has a wide variety of biological roles in numerous systems including the immune, nervous, and endocrine systems [31, 32]. IL-6 was seen to induce Bcell growth and antibody production, which is why it was originally named B-cell stimulatory factor 2, or BSF2. It is well known that a large amount of IL-6 is secreted in response to inflammatory stimuli such as Toll-like receptor ligands and proinflammatory cytokines including IL-1, IL17 , and tumor necrosis factor (TNF)- $\alpha$ to combat infections and, finally, to promote inflammation. Studies have shown that 6-gingerol inhibited the TNF- $\alpha$, and IL- $1 \beta$-induced increase in the p38-dependent NF- $\kappa \mathrm{B}$ activation and expression of pro-inflammatory genes of IL-6 and IL-8 in normal prostatic epithelial cells [33]. Essential oils such thyme is effective in reducing Atopic dermatitis symptoms and for decreasing superoxide radical, degranulated mast cells, and IgE [34]. Thyme and carvacrol as their principal bioactive compounds decrease levels of the proinflammatory cytokines IL- $1 \beta$, IL- 6 , and TNF- $\alpha$. However, mechanisms mediating these suppressive effects are unclear [35]. Borneol, another compound present in thyme, has been also described as an anti-inflammatory since its dietary supplementation significantly decreases the concentration of the proinflammatory cytokines IL-1 $\beta$ and IL-6 in mice [36]. This study was aimed to investigate the effects of using Thyme and Ginger powder on growth performance, biochemical and Immunological parameters of rats.

\section{Materials and Methods}

\subsection{Animals}

Adult male albino rats of Wistar strain weighing about 75$83 \mathrm{~g}$ and 8-10 weeks old were used for the present study. The animals were purchased from the animal house in King Saud University, Riyadh, Saudi Arabia. The rats were kept in ventilated, clean, sterile, plastic cages with wood shavings under conventional conditions and had free access to food and water. All animal experiments were carried for period 32 days and according to the guidelines of the Institutional Animals Ethics Committee. The animal room was well ventilated with a $12 \mathrm{~h}$ light/dark cycle throughout the experimental period.

\subsection{Experimental Design}

Rats were then divided into 3 groups of 5 animals in each group. Group I (control) rats received normal commercial basal diet contained CP $17 \%$ and Metabolizable energy $2415 \mathrm{Kcal} / \mathrm{kg}$ (According to feed stuffs ingredient analysis table 2012 edition) and its composition according to table 1. Group II (thyme) rats fed with normal commercial basal diet contained $5 \%$ thyme (5gm / 100gm basal diet). Group III (Ginger) rats fed with normal commercial basal diet contained $5 \%$ ginger powder (5gm / 100gm basal diet). Weights were recorded at the beginning of experiment and at the end of the experimental period. Also at the end of experimental period, the food intake (FI), food conversion ratio $(\mathrm{FCR})$ and body gain $(\mathrm{BG})$ per rat in each group were calculated.

Table 1. Commercial rats Diet Composition.

\begin{tabular}{ll}
\hline Ingredients & Percent (\%) \\
\hline Alfalfa pellets & $35 \%$ \\
Maize Broken & $15 \%$ \\
Barley & $15 \%$ \\
White Sorghum & $10 \%$ \\
Sunflower white & $5 \%$ \\
Sunflower black & $5 \%$ \\
Wheat & $10 \%$ \\
Safflower & $5 \%$ \\
\hline
\end{tabular}

\subsection{Blood Samples Collection}

At the end of the experimental period, the animals were fasted for 12 hours. The blood samples were obtained from orbital venous plexus. The blood was collected and then centrifuged at $3000 \mathrm{~g}$ for $10 \mathrm{~min}$ using bench top centrifuge. Sera were separated and were collected using dry Pasteur pipette. Labeled and stored in the refrigerator at $-20^{\circ} \mathrm{C}$ for analyses.

\subsection{Biochemical Measurements}

The total protein was measured by colorimetric biuret test [37], Albumin and globulins was measured by the method described by [38]. The kidney functions were indicated by measuring urea concentration according to the method of [39], and Creatinine according to method of [40]. Liver 
functions were indicated by GOT and was estimated by [41], Alkaline phosphatase (ALP) was measured based on colorimetric assay with endpoint method as described by [42], Lipid profiles as total cholesterol (TC) and triacylglycerols (TG) estimated by kits according to method described by [43], high density lipoprotein (HDL) and low density lipoprotein (LDL) was measured by kits as method indicated by [44].

\subsection{IL-6 Measurements}

IL-6 levels were analyzed by using validated ELISA kits $\left(E{ }^{\circledR}\right.$ life sciences) which is a complete kit for the quantitative determination of IL-6 in biological fluids. The kit uses a monoclonal antibody of rats IL- 6 immobilized on a microtiter plate to bind the IL-6 in the sample. A recombinant IL-6 standard is provided in the kit. After a short incubation the excess sample or standard is washed out and a biotinylated monoclonal antibody of IL- 6 is added. This antibody binds to the IL-6 captured on the plate. After a short incubation the excess antibody is washed out and Streptavidin conjugated to Horseradish peroxidase is added, which binds to the biotinylated IL-6 antibody. Excess conjugate is washed out and substrate is added. After a short incubation, the enzyme reaction is stopped and the color generated is read at $450 \mathrm{~nm}$. The measured optical density is directly proportional to the concentration of IL-6 in either standards or samples $[45,46]$.

\subsection{Statistical Analysis}

All values are given as means \pm S.E. Statistical analyses were performed by using SPSS VERSION 20 using one way ANOVA test for multiple groups' comparison. Differences among means were analyzed using Duncan's test, with $p<$ 0.05 considered as significant.

\section{Results}

\subsection{Effect of Thyme and Ginger on Growth Performance and Feed Efficiency}

The obtained results showed that there were significant differences in final body weight, body gain and feed efficiency between thyme, Ginger and control groups where the highest significant value was in group supplemented with thyme followed by group supplemented by ginger in comparison with control group fed on basal diet (at $\mathrm{P}<0.05$ ) as shown in table 2 and figure. 1.

Table 2. Effect of thyme and ginger on growth performance and feed efficiency.

\begin{tabular}{|c|c|c|c|c|}
\hline & Control & Thyme & Ginger & F-Ratio; P-Value \\
\hline Initial Body weight & $79 \pm 1.15$ & $82.67 \pm 1.76$ & $82.67 \pm 2.03$ & $\mathrm{~F}=1.57 ; \mathrm{P}=0.28$ \\
\hline Final body weight & $147.67 \pm 1.45^{\mathrm{c}}$ & $172.33 \pm 1.2^{\mathrm{a}}$ & $157.67 \pm 1.45^{\mathrm{b}}$ & $\mathrm{F}=81.49 ; \mathrm{P}=0.001$ \\
\hline Body Gain & $68.67 \pm 2.19^{\mathrm{b}}$ & $89.67 \pm 2.85^{\mathrm{a}}$ & $75 \pm 3.06^{\mathrm{b}}$ & $\mathrm{F}=15.67 ; \mathrm{P}=0.004$ \\
\hline Feed efficiency & $1.6 \pm 0.04^{\mathrm{a}}$ & $1.06 \pm 0.04^{\mathrm{c}}$ & $1.34 \pm 0.07^{\mathrm{b}}$ & $\mathrm{F}=32.91 ; \mathrm{P}=0.001$ \\
\hline
\end{tabular}

The groups which have different superscript letters in the same raw are significantly $(\mathrm{P}<0.05)$.

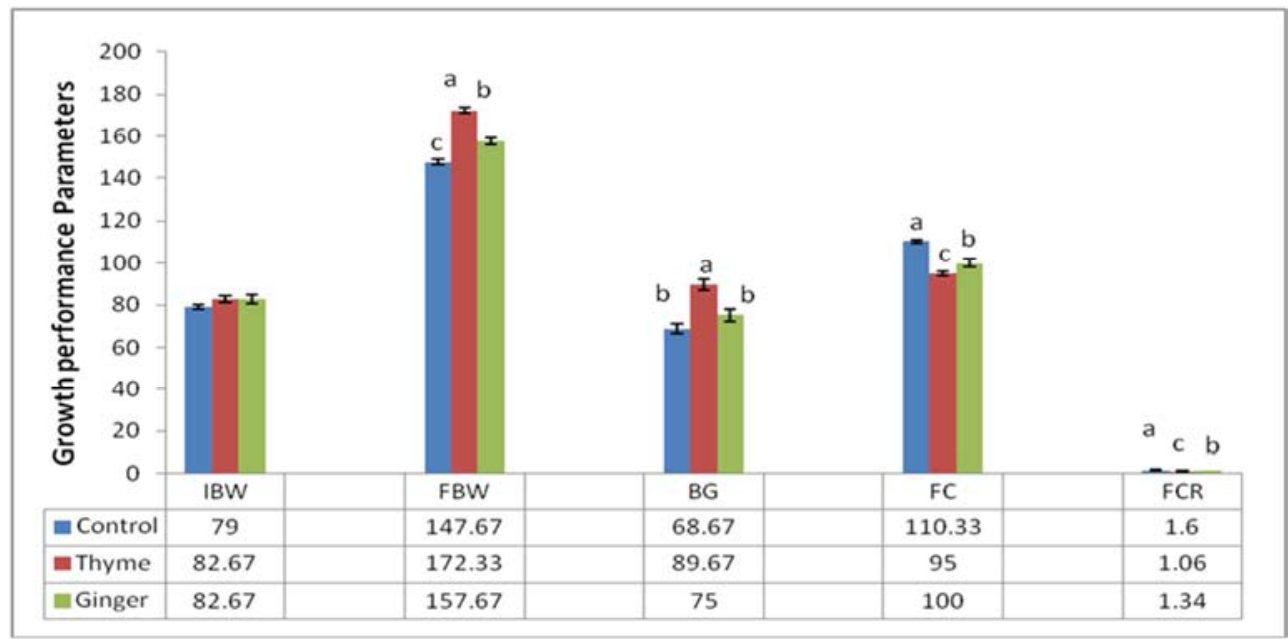

Figure 1. Effect of thyme and Ginger on growth performance and feed efficiency in rats diet.

\subsection{Effect of Thyme and Ginger on Biochemical Parameters of Rats Serum}

\subsubsection{Effect of Thyme and Ginger on Serum Total Proteins, Albumin, Total Globulins, ALP and GOT}

Thyme and ginger recorded no significant changed of serum total proteins and albumin, meanwhile total globulins were significantly increased in comparing with control group. Moreover, there was a significant increase of serum GOT in ginger group and no significant change of it in thyme group; Meanwhile ALP was significantly increased in thyme and ginger groups as shown in Table 3. 
Table 3. Effect of thyme and ginger on serum total proteins, albumin, total globulins, ALP and GOT.

\begin{tabular}{llllll}
\hline & $\begin{array}{l}\text { T. proteins } \\
(\mathbf{g} / \mathbf{d l})\end{array}$ & $\begin{array}{l}\text { Albumin } \\
(\mathbf{g} / \mathbf{d l})\end{array}$ & $\begin{array}{l}\text { T. globulin } \\
(\mathbf{g} / \mathbf{d l})\end{array}$ & $\begin{array}{l}\text { GOT } \\
(\mathbf{u} / \mathbf{l})\end{array}$ & $\begin{array}{l}\text { ALP } \\
(\mathbf{u} / \mathbf{l})\end{array}$ \\
\hline Control & $4.50 \pm 0.03$ & $3.74 \pm 0.11$ & $0.30 \pm 0.30^{\mathrm{b}}$ & $30.62 \pm 1.20^{\mathrm{b}}$ & $120.33 \pm 10.97^{\mathrm{b}}$ \\
Thyme & $4.81 \pm 0.20$ & $3.75 \pm 0.22$ & $1.31 \pm 0.13^{\mathrm{a}}$ & $31.51 \pm 1.03^{\mathrm{b}}$ & $168.67 \pm 8.99^{\mathrm{a}}$ \\
Ginger & $4.67 \pm 0.26$ & $3.46 \pm 0.29$ & $1.43 \pm 0.14^{\mathrm{a}}$ & $42.61 \pm 2.34^{\mathrm{a}}$ & $167.67 \pm 10.48^{\mathrm{a}}$ \\
F-Ratio; & $\mathrm{F}=0.69$ & $\mathrm{~F}=0.55$ & $\mathrm{~F}=9.32$ & $\mathrm{~F}=16.81$ & $\mathrm{~F}=7.36$ \\
P-Value & $\mathrm{P}=0.54$ & $\mathrm{P}=0.61$ & $\mathrm{P}=0.014$ & $\mathrm{P}=0.003$ & $\mathrm{P}=0.024$ \\
\hline
\end{tabular}

The groups which have different superscript letters in the same column are significantly different where the high significant group which has superscript a followed by $b$ then $c$. $(\mathrm{P}<0.05)$.

\subsubsection{Effect of Thyme and Ginger on Serum TG, TC, HDL and LDL}

Thyme highly significantly decreased serum TG, while ginger significantly decreased it. Regarding to TC, thyme and ginger decreased it significantly. On the other hand, thyme and ginger groups recorded non-significant change of serum HDL, even though they revealed that a significant decrease in thyme group and a highly significant decreased of LDL in ginger group in comparing with control group as shown in Table 4.

Table 4. Effect of thyme and ginger on serum $T G, T C, H D L$ and $L D L$.

\begin{tabular}{lllll}
\hline & $\begin{array}{l}\text { TG } \\
(\mathbf{m g} / \mathbf{d l})\end{array}$ & $\begin{array}{l}\text { TC } \\
(\mathbf{m g} / \mathbf{d l})\end{array}$ & $\begin{array}{l}\text { HDL } \\
(\mathbf{m g} / \mathbf{d l})\end{array}$ & $\begin{array}{l}\text { LDL } \\
(\mathbf{m g} / \mathbf{d l})\end{array}$ \\
\hline Control & $90.94 \pm 2.03^{\mathrm{a}}$ & $58.08 \pm 2.98^{\mathrm{a}}$ & $19.90 \pm 0.28$ & $19.29 \pm 0.49^{\mathrm{a}}$ \\
Thyme & $36.36 \pm 3.89^{\mathrm{c}}$ & $34.48 \pm 5.95^{\mathrm{b}}$ & $20.23 \pm 0.16$ & $13.77 \pm 0.66^{\mathrm{b}}$ \\
Ginger & $55.69 \pm 5.52^{\mathrm{b}}$ & $39.89 \pm 2.02^{\mathrm{b}}$ & $18.15 \pm 0.96$ & $9.60 \pm 0.62^{\mathrm{c}}$ \\
F-Ratio; & $\mathrm{F}=46.27$ & $\mathrm{~F}=9.48$ & $\mathrm{~F}=3.64$ & $\mathrm{~F}=67.11$ \\
$\mathrm{P}-$ Value & $\mathrm{P}=0.001$ & $\mathrm{P}=0.014$ & $\mathrm{P}=0.092$ & $\mathrm{P}=0.001$ \\
\hline
\end{tabular}

The groups which have different superscript letters in the same column are significantly different where the high significant group which has superscript a followed by b then $\mathrm{c}$. $(\mathrm{P}<0.05)$.

\subsubsection{Effect of Thyme and Ginger on Serum Urea and Creatinine}

Concerning the results of serum urea and Creatinine, which is shown in Table 5, there was a significant decreasing of serum urea in thyme group, meanwhile a non-significant change of it in ginger group in comparing with control group. On the other hand, serum Creatinine recorded a highly significantly decrease in thyme group, even though it recorded a significantly increase in ginger group.

Table 5. Effect of thyme and ginger on serum Urea and Creatinine.

\begin{tabular}{lll}
\hline & Urea $(\mathbf{m g} / \mathbf{d l})$ & Creatinine $(\mathbf{m g} / \mathbf{d l})$ \\
\hline Control & $32.64 \pm 1.65^{\mathrm{a}}$ & $0.72 \pm 0.04^{\mathrm{b}}$ \\
Thyme & $17.25 \pm 1.15^{\mathrm{b}}$ & $0.44 \pm 0.03^{\mathrm{c}}$ \\
Ginger & $28.87 \pm 2.26^{\mathrm{a}}$ & $0.88 \pm 0.04^{\mathrm{a}}$ \\
F-Ratio; & $\mathrm{F}=21.13$ & $\mathrm{~F}=41.97$ \\
P-Value & $\mathrm{P}=0.002$ & $\mathrm{P}=0.001$ \\
\hline
\end{tabular}

The groups which have different superscript letters in the same column are significantly different where the high significant group which has superscript a followed by $b$ then $c,(P<0.05)$.

\subsection{Measurement of IL6 Level in Serum Samples}

In our results, Thyme had opposite effects on production of IL6; whereas there was significant decrease in serum IL-6 concentrations of the experimental group (Thyme administration) relative to the control group as shown in table 6 and Figure 2.

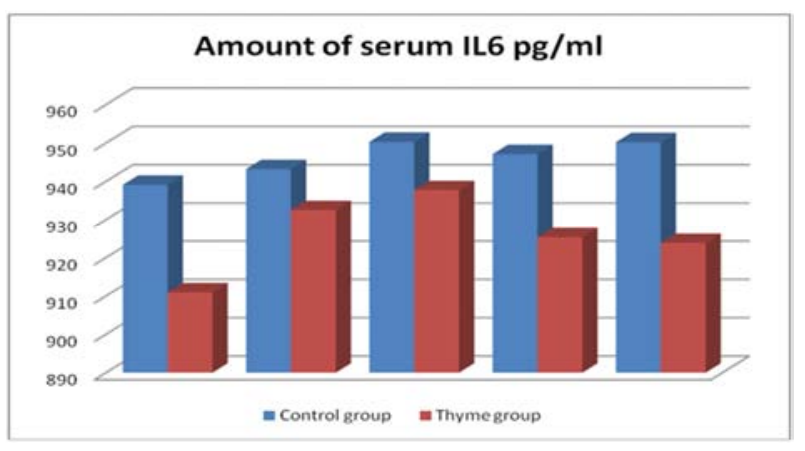

Figure 2. Amount of serum IL-6 in control and Thyme groups.

Meanwhile there was significant increase in serum IL-6 concentrations of the experimental group (Ginger administration) relative to the control group following at the end of week 6 of rats rearing as shown in table 6 and Figure 3.

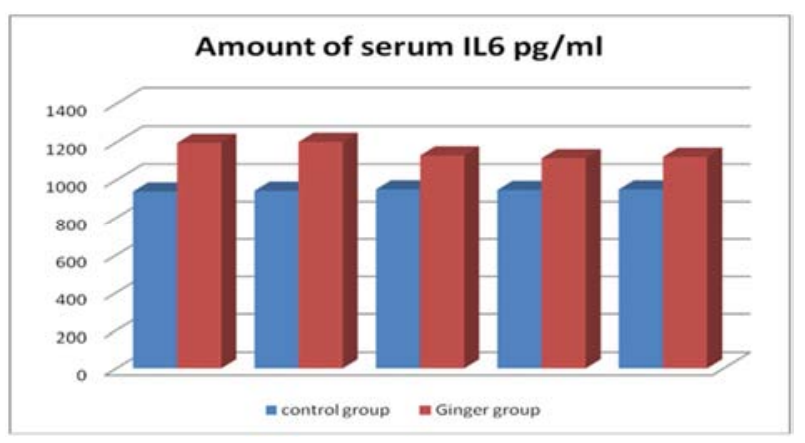

Figure 3. Amount of serum IL-6 in control and Ginger groups. 
Table 6. Effect of thyme and ginger on amount of serum IL6.

\begin{tabular}{lllll}
\hline & Control & Thyme & Ginger & $\begin{array}{l}\text { F-Ratio; } \\
\text { P-Value }\end{array}$ \\
\hline $\begin{array}{l}\text { IL6 } \\
\mathrm{pg} / \mathrm{ml}\end{array}$ & $945.98 \pm 2.15^{\mathrm{b}}$ & $923.46 \pm 4.9^{\mathrm{b}}$ & $1153.70 \pm 18.95^{\mathrm{a}}$ & $\begin{array}{l}\mathrm{F}=124.71 ; \\
\mathrm{P}=0.001\end{array}$ \\
\hline
\end{tabular}

The groups which have different superscript letters in the same raw are significantly different where the high significant group which has superscript a followed by $\mathrm{b}(\mathrm{P}<0.05)$.

\section{Discussion}

The results in table 2 and figure 1 revealed that the final body weight, body gain and feed efficiency values had significant differences between the treatments, groups supplemented with 5\% thyme and 5\% ginger, in comparison to Control group fed on basal diet where the best results regarding the growth performances were in group supplemented with $5 \%$ thyme then group fed on basal diet with 5\% ginger in comparison with control group. These results agreed with that reported by $[15,26]$ but disagreed with results reported by [47].

The results in table 3 revealed that thyme and ginger insignificantly changed serum total protein and albumin which agree with [23] who recorded that thyme powder didn't affect serum protein and albumin of broiler chicks but this result disagree with [48]. Moreover Ginger significantly increased serum total globulins of rats in comparison with control one which agrees with the result of [48] who showed that increased serum globulins of rats received ginger. Using of thyme and ginger increase serum level of GOT and ALP in comparison with control which disagree with [78] who stated that ginger (1\%) decreased serum AST and ALP of rats and [49] who reported that the increased serum AST of injected rat with $\mathrm{CCl} 4$ restored to normal by ginger, the difference may be due to the used dose. also, [50] revealed that thyme $2 \mathrm{gm} / \mathrm{Kg}$ recorded decrease of serum AST of broiler chicken our result may be differ as difference in dose. ALP is commonly found in biliary tree and bile ducts, a blockage in this system will cause an elevated ALP [51]. In concern to the results in table 4 which revealed deceased serum level of TC, TG and LDL which agree with $[22,52$, 53] meanwhile these results disagree with [24] who recorded increase plasma level of triglycerides and LDL-cholesterol in broilers with thyme oil and [23] who stated no significant influence of thyme on LDL- cholesterol in broilers but [54] indicated that Ginger may improve hypercholesterolemia by modifying lipoprotein metabolism enhanced uptake of LDL by increasing LDL receptors. Reduction of triglycerides and cholesterol noticed with thyme was attributed to the lowering effect of thymol on HMG-Co A reductase the rate-limiting enzyme of cholesterol synthesis [55-56]. [57] Suggested that ginger stimulates the conversion of cholesterol to bile acids, an important pathway of elimination of cholesterol from the body. Cholesterol is eliminated from the body either unchanged or after conversion to bile acids. Small changes in the composition of bile can result in crystallization of cholesterol as gall stone also cholesterol is a major constituent of gall stones [58]. This is the first record for increasing of ALP with ginger use which may indicate that overuse of ginger may be predisposing factor of gall stone as it may change the bile composition by increasing formation of bile acids to eliminate the cholesterol, moreover [59] reported that immune activation of some herbal agents is one of suspected mechanism of liver injury. Regarding to the results in table 5 recorded that thyme reduced serum urea and Creatinine which is in agreement with $[60,61]$ as thyme maintains normal kidney functions by maintaining normal level of oxidative stress parameters, reduces MDA, and prevents histopathological changes in the kidney [61]. On the other hand, ginger insignificantly reduced serum urea and significantly increased serum Creatinine, these results were in disagreement with the results of [62] who recorded that a beneficial effect of ginger for urea and Creatinine taking away from plasma of normal rats and [63] who stated that ginger extracts (twice a week for six consecutive weeks) reduced urea and Creatinine levels in normal rat when compared to control one. The disagreement may be due to the difference in the administration regime. As the increased of serum Creatinine considered one of the indicator for kidney injury [64] and misusing of ginger must be avoided.

Interleukin 6 act as a pro-inflammatory cytokine, it is encoded by the IL- 6 gene. IL- 6 secretion during infection leads to inflammation and stimulation of the immune response [65]. The key finding of this study is that ginger increase level of serum IL- 6 concentrations in rats, these results was agreed with [66] who mentioned that the administration of ginger resulted in over increased in the production of IL-6. Also [67] illustrated that the oral administration of squeezed ginger increased the production of IL-6 in rat leukemic monocytes. While [26] mentioned that ginger contains several compounds and enzymes including gingerdiol, gingerol, gingerdione and shogaols. These compounds have been blocking the production of interleukins, and inflammatory markers $[27,28]$ and have antimicrobial, antioxidative and pharmacological effects [29]. Thyme significantly decrease production of serum IL-6 in mice and these results agreed with [68] who mentioned that IL-6 gene expression in mice fed with any of thyme extracts was reduced until level of nonactivated control cells which expression was decreased to half compared to activated cells. Thyme may act as effective inhibitors of LDL-induced proinflammatory cytokines (TNF- $\alpha$, IL-1 $\beta$, and IL-6) secretion.

\section{Conclusion}

Nowadays medicinal herbs are used extensively and many believed that they are safe. On our best of knowledge these the first study which recorded the increasing of ALP and GOT with ginger and increase of ALP with thyme even their positive effect on the other concerned parameters in our study. Ginger increase level of serum IL-6 concentrations, while thyme decrease its level in serum. Although Thyme supplementation group improved the growth performance 
and feed efficiency of rats in comparison to ginger supplementation group and control group. So using of Medicinal herbs must be with restriction and further studies are required for proven the safe use of theses herbs.

\section{Acknowledgment}

I am deeply grateful to Dr. Ola Talkhan., associate professor of biochemistry, faculty of Science, Hail University, KSA for making it possible to carry out the biochemistry part of this work in their department.

\section{References}

[1] Demir, E.; Kilinc, K.; Yildirim, Y.; Dincer, F. and Eseceli, H., 2008. Comperative effects of mint, sage, thyme and flavomycin in wheatbased broiler diets. Archive Zootechnica, 11:54-63.

[2] Mansoub, N. H., 2011. Comparison of effects of using Nettle (Urticadioica) and probiotic on performance and serum composition of broiler chickens. Global Veterinaria, 6(3): 247250 .

[3] Abd El-Latif, S. A.; Faten, A. A. and ElKaiaty, A. M., 2002. Effect of feeding dietary thyme, black cumin. Dianthusand, fennel on productive and some metabolic responses of growing Japanese quail. Egypt Poult. Sci., 22(1): 106-125.

[4] Didry, N. L. Dubreuil, and M. Pinkas, 1994. “Activity of thymol, carvacrol, cinnamaldehyde and eugenol on oral bacteria," Pharmaceutica Acta Helvetiae, vol. 69, no. 1, pp. $25-28$.

[5] Aeschbach, R, J. L"oliger, B. C. Scott, Murica A, Buttler, J, Halliwell B, Aruoma, OI 1994. "Antioxidant actions of thymol, carvacrol, 6-gingerol, zingerone and hydroxytyrosol," Food and Chemical Toxicology, vol. 32, no. 1, pp. 31-36.

[6] Vincent, H. V., 2002. Carvacrol and thymol reduce swine waste odour and pathogens stability of oils. Curr. Microbiol. 44: 38-43.

[7] Fujisawa, S. and Y. Kadoma, 1992. Effect of phenolic compounds on the polymerization of methyl methacrylate," Dental Materials, vol. 8, no. 5, pp. 324-326.

[8] Segvi Klari, M, I. Kosalec, J. Masteli, E. Pieckov'a, and S. Pepeljnak, 2007. Antifungal activity of thyme (Thymus vulgaris L.) essential oil and thymol againstmoulds fromdamp dwellings," Letters in Applied Microbiology, vol. 44, no. 1, pp. 36-42.

[9] Cheij R. 1984. McDonal Encyclopedia of medicinal plants. McDonal and Co. (publishers) London. 209, 309, 313p.

[10] Mossa JS., 1987. Medicinal plants of Saudi Arabia, Pub. By king Saudi university libraries, Riyadh;.244p.

[11] Guseinov DIA, Kagramanov KM, Kasumov FIU, Akhundov RA., 1987. Research on the chemical composition and aspects of the pharmacological action of the essential oil of Kochi thyme (thymes kotschyanus Boiss.) Farmak Toksikol. 50: 7374.

[12] Braga, P, C, M. Dal Sasso, M. Culici, T. Bianchi, L. Bordoni, and L. Marabini, 2006. Anti-inflammatory activity of thymol: inhibitory effect on the release of human neutrophil Elastase,"Pharmacology, vol. 77, no. 3, pp. 130-136.

[13] Suzuki, Y. and H. Furuta, 1988. Stimulation of guinea pig neutrophil superoxide anion-producing system with thymol, Inflammation, vol. 12 , no. 6, pp. 575-584.

[14] Mikaili, P.; Mohammad Nezhady M. A.; Shayegh J. and Asghari, M. H., 2010. Study of antinociceptive effect of Thymus vulgaris and Foeniculumvulgare essential oil in mouse. Int. J. Academic Res., 2(6): 374-376. Part II.

[15] Adem, Y. S, Soner B., Gonca A., Olcay H., Talat Y., Gouranga B., 2015. Growth performance and antioxidant enzyme activities in rainbow trout (Oncorhynchusmykiss) juveniles fed diets supplemented with sage, mint and thyme oils. Fish PhysiolBiochem 41:165-175.

[16] Schwarz K., Ernst H., Ternes W., 1996. Evaluation of antioxidant constituents of thyme. J. Sci. Food Agric.; 70: 217-223.

[17] Guillen, M. D. Manzanoz MJ., 1998. Study of the composition of the different parts of a Spanish thymus vulgaris L. Plant Food Chem. 63:373-383.

[18] Wang, M. Li J, Ho GS, Peng X, Ho CT, 1998. Isolation and identification of antioxidative flavonoid glycosides from thyme (Thymes valgaris L.) J food lipids.5:313-321.

[19] Arcila-Lozano C., G. Loarca-Pina, and S. Lecona-Uribe, 2004. Oregano properties, composition and biological activity, Archivos Latinoamericanos de Nutricion, vol. 54, no. 1, pp. $100-111$.

[20] Bozin, B. N., Mimica-Dukic, I. Samojlik, and E. Jovin, 2007. Antimicrobial and antioxidant properties of Rosemary and Sage (Rosmarinus officinalis L. and Salvia officinalis L., Lamiaceae) essential oils, Journal of Agricultural and Food Chemistry, vol. 55, no. 19, pp. 7879-7885.

[21] Alma, M. H. A., Mavi, A. Yildirim, M. Digrak, and T. Hirata, 2003. "Screening chemical composition and in vitro antioxidant and antimicrobial activities of the essential oils from Origanum syriacum L. growing in Turkey," Biological and Pharmaceutical Bulletin, vol. 26, no. 12, pp. 1725-1729.

[22] Ali, M. N, Hassan MS, Abdel-Ghany FA, 2007. Effect of strain, type of natural antioxidant and sulphate on productive, physiological and hatching performance of native laying hens. Int. J. Poult. Sci. 6: 539-554.

[23] Toghyani, M., Tohidil M., Gheisari A A. and Tabeidian S., 2010. Performance, immunity, serum biochemical and hematological parameters in broiler chicks fed dietary thyme as alternative for an antibiotic growth promoter. African Journal of Biotechnology Vol. 9(40), pp. 6819-6825.

[24] Bolukbasi, S. C., Erhan, M. K., Özkan, A., 2006. Effect of dietary thyme oil and vitamin $\mathrm{E}$ on growth, lipid oxidation, meat fatty acid composition and serum lipoproteins of broilers, South Afric. J. Anim. Sci. 36(3): 189-196.

[25] Vivian, U., Oleforuh-Okoleh, Harriet M. Ndofor-Foleng, Solomon O. Olorunleke \& Joesph O. Uguru., 2015. Evaluation of Growth Performance, Haematological and Serum Biochemical Response of Broiler Chickens to Aqueous Extract of Ginger and Garlic. Journal of Agricultural Science; 7: $230-236$ 
[26] Zhao, X., Yang, Z. B., Yang, W. R., Wang, Y., Jiang, S. Z., \& Zhang, G. G., 2011. Effects of ginger roots (Zingiberofficinale) on laying performance and antioxidant status of laying hens and on dietary oxidation stability. Poultry Science, 90, 1720-1727.

[27] Lantz, R. C, Chen GJ, Sarihan M, Solyom AM, Jolad SD, Timmermann BN, 2007. The effect of extracts from ginger rhizome on inflammatory mediator production. Phytomedicine, 14:123-128.

[28] Thomson, M., Al-Qattan, K. K., Al-Sawan, S. M., Alnaqeeb MA, Khan I, Ali M., 2002. The use of ginger (ZingiberofficinaleRosc.) as a potential anti-inflammatory and antithrombotic agent. Prostaglandins Leukot Essent Fatty Acids, 67:475-478

[29] Ali, B. H., Blunden, G., Tanira, M. O., \&Nemmar, A., 2008. Some phytochemical, pharmacological and toxicological properties if ginger (ZingiberofficinaleRoscoe): A review of recent research. Food Chemistryand Toxicology, 46, 409-420.

[30] Surh, Y., 1999. Molecular mechanisms of chemopreventive effects of selected dietary and medicinal phenolic substances," Mutation Research, vol. 428, no. 1-2, pp. 305-327.

[31] Kamimura, D., Ishihara, K., Hirano T., 2003. IL-6 signal transduction and its physiological roles: the signal orchestration model. Rev Physiol Biochem Pharmacol 149:138 .

[32] Taga, T., Kishimoto T., 1997. Gp130 and the interleukin-6 family of cytokines. Annu Rev Immunol 15:797-819.

[33] Nonn, L. D. Duong, and D. M. Peehl, 2007. "Chemopreventive anti-inflammatory activities of curcumin and other phytochemicals mediated by MAP kinase phosphatase-5 in prostate cells," Carcinogenesis, vol. 28, no. 6, pp. 1188-1196.

[34] Seo, Y. M. and Jeong, S. H., 2015. Effect of blending oil of lavender and thyme on oxidative strees, immunity and skin condition in atopic dermatitis induced mice. J Korean Acad Nurs.45(3):367-77.

[35] Bukovska, A. S., Cikos, S. Juhas, G. Il'kova, P. Rehak, and J. Koppel, 2007 "Effects of a combination of thyme and oregano essential oils on TNBS-induced colitis in mice," Mediators of Inflammation, vol. 2007, Article ID 23296, p. 9.

[36] Juhás, Š., Čikoš, Š., Czikková, S., Veselá J, Il’ková G, Hájek T, Domaracká K, Domaracký M, Bujňáková D, Rehák P, Koppel J 2008: Effects of borneol and thymoquinone on TNBSinduced colitis in mice. Folia Biol-Prague 54: 1-7.

[37] Josephson, B. and Gyllensward, C., 1957. The development of the protein fractions and of cholesterol concentration in the serum of normal infants and children. Scandinavian journal of clinical and laboratory investigation, 9(1): 29-38.

[38] Doumas, B. T., Doumas, B. T., Watson, W. A., \& Biggs, H. G., 1971. Albumin standards and the measurement of serum albumin with bromcresol green. Clinica Chimica Acta. 31(1), 87-96.

[39] Tobacco A, Meiattini E, Moda P, 1979. Tarli Simlified enzymatic/Colorimetric serum urea nitrogen determination. Clin Chem.; 25: 336-337.

[40] Bartels, H., and Böhmer M., 1971. Eine Mikromethode zur Kreati - ninbestimmung. Clinica Chimica Acta; 32: 81-5.
[41] Schumann, G., Bonora, R., Ceriotti, F., Ferard, G., Ferrero, C. A. and Franck, P. F. H., 2002. International Federation of Clinical Chemistry and Laboratory Medicine. Part 5: reference procedure for the measurement of catalytic concentration of aspartate aminotransferase. Clinical Chemistry and Laboratory Medicine, 40, 725-733.

[42] Rick, W., 1990. Klinische Chemie und Mikroskopi, $6^{\text {th }}$ Edition, Springer, Verlag, Berlin, 294.

[43] Bucolo, G. and David H 1973. Quantitative determination of serum triglycerides by use of enzymes. Clinical chemistry: 19(5): 476-482.

[44] Lopes-Virella, M. F, Stone P, Ellis S, Colwell JA. 1977. Cholesterol Determination in High-Density Lipoproteins Separated by Three Different Methods clinical chemistry, 23(5): $882-4$.

[45] Chard, T., 1990. An Intro. to Radioimmunoassay \& Related Tech.", 4th Ed., Elsevier, Amsterdam.201.

[46] Tijssen, P., 1985. In Practice \& Theory of Enz. Immunoassays", (1985), Elsevier, Amsterdam.145.

[47] Mehdipour, Z., Afsharmanesh, M. and Sami, M., 2014. Effects of supplemental thyme extract (Thymus vulgaris L.) on growth performance, intestinal microbial populations, and meat quality in Japanese quails. Comp Clin Pathol (2014) 23:1503-1508.

[48] Lebda, M. A, Taha, N M, Korshom, MA, Mandour, A A and Raghda, G I, 2013. ginger (zingiber officinale) potentiate paracetamol induced chronic hepatotoxicity in rats. Journal of medicinal plants research, 7(42): 3164-3170.

[49] Sohair, S. Ahmad, Hanan, M. Sobhy, Elham, A. Mohamed 2, Hanan, A. Azoz and Hanan, A. Sultan., 2014. Comparative studies of curcuma, ginger and rosemary on DNA damage, cytogenicity and biochemical parameters in rats. J.Vet.Nov. (1).

[50] Tawfeek, F. Kh. and Mustafa N. G., 2012. Effects of coriander, thyme, vanadyl and tungstate on some biochemical parameters in broiler chickens. Iraqi Journal of Veterinary Sciences, Vol. 26, Supplement II, 2012 (71-75).

[51] Basten, G., 2010. In: introduction to clinical biochemistry: Interpreting blood result pp 47.

[52] Ramudu SK, Mallikarjuna K. and Kesireddy S R., 2011. Efficacy of ethanolic extract of ginger on kidney lipid metabolic profiles in diabetic rats. Int J Diabetes Dev Ctries. 31(2): 97-103.

[53] Radwan, N. L., Hassan, R. A., Qota, E. M., Fayek, H. M., 2008. Effect of natural antioxidant on oxidative stability of eggs and productive and reproductive performance of laying hens. Int. J. Poult. Sci. 7: 134-150.

[54] Bhandari, U., Kanojia R, Pillai KK., 2005. Effect of ethanolic extract of Zingiber officinale on dyslipidaemia in diabetic rats. J Ethnopharmacol.; 97: 227-30.

[55] Case, G. L., He, L., Mo, H., Elson, C. E., 1995. Induction of geranylPyrophosphate pyrophosphatase activity by cholesterol suppressive isoprenoids. Lipids, 30: 357-359.

[56] Lee, K. W., Everts, H., Kappert, H. J., Frehner, M., Losa R, Beynen AC., 2003. Dietary Carvacrol lowers body weight gain but improves feed conversion in female broiler chickens. J. Appl. Poult. Res. 12: 394-399. 
[57] Srinivasan, K., and Sambaiah, K., 1991. The effect of spices on cholesterol 7alpha-hydroxylase activity and on serum and hepatic cholesterol levels in the rat. Int J Vitam Nutr Res.;61: $363-9$.

[58] Murray, R. K., Bender, D. A., Botham, K. M., Kennelly, P. J., Rodwell, V. W. and WEILL PA 2009. Harper's illustrated biochemistry $28^{\text {th }}$ EdMcGraw-Hill companies pp 224, 459.

[59] Leonard, B. S., Herbert, L. B., Victor, J. N., and Wang, G., 2015. Herbal products and the liver: a review of adverse effects and mechanisms. Gastroenterology, 148: 517-532.

[60] Monira, A. A., and Naima, Z. M., 2012. Evaluation of protective and antioxidant activity of thyme (thyme vulgaris) extract on paracetamol-induced toxicity in rats. Australian journal of basic and applied sciences. 6(7): 467-474.

[61] Abu-Raghif, A. R, Qasim, B. J., Abady, A. H., and Sahib, H. B., 2015. Effects of aqueous thyme extract against ciplastin induced nephrotoxicity in rabbits.int.j. pharm. Sci. rev. res., 30(1), 35: 190-194.

[62] Mehardad, A., Messripour, M., and Ghobadipour, M., 2007. The effect of ginger extract on blood urea nitrogen and Creatinine in mice). Pakistan journal of biological sciences, 10(17), $2968-2971$.

[63] 63. Manal, A. H., Sanaa, A. A. and El-Rigal, N. S., 2012. Therapeutic potential of ginger against renal injury induced by carbon tetrachloride in rats. The scientific world journal, 840421. Published online 2012 April 1. doi: $10.1100 / 2012 / 840421$.

[64] Khan, M. R., Rizvi, W., Khan, G. N., Khan, R. A., and Shaheen, S., 2009. Carbon tetrachloride-induced nephrotoxicity in rats: protective role of Digera muricata.Journal of ethnophamacology, 122(1): 91-99.

[65] Nishimoto, N., 2006. Interleukinleukin-6 in rheumatoid arthritis. Curr. Opin. Rheumatol. 18(3):277-281.

[66] Amal, A. M. Hassan, Manal, F. Ismail and Hanaa M. Mohamed 2015. Effect of methotrexte combined with Ginger, Silymarin or propolis on the mRNA expression levels of cytochrome P450 oxidoreductase (POR) Caspase 3(CASP-3) and interlukin 6(IL-6). Afr. J. Biotechnol. Vol. 14(8), pp 695701 .

[67] Ueda, H., Ippoushi, K., Takeuchi, A., 2010. Repeated oral administration of a squeezed ginger (zingiber officinale) extract augmented the serum corticosterone level and had antiinflammatory properties. Biosci. Biotechnol. Biochem. 74(11): 2248-2252.

[68] Ocana, A. and Reglero, G., 2012. Effects of Thyme Extract Oils (fromThymus vulgaris, Thymus zygis, and Thymus hyemalis ) on Cytokine Production and Gene Expression of oxLDL-Stimulated THP-1-Macrophages. Journal of Obesity Volume 2012, p 1-11. 